\title{
Comparative assessment of raw and digested pig slurry treatment in bioelectrochemical systems
}

\author{
Míriam Cerrillo, Judit Oliveras, Marc Viñas, August Bonmatí * \\ IRTA, GIRO Joint Research Unit IRTA-UPC, Torre Marimon, E-08140, Caldes de Montbui, Barcelona, Spain
}

\section{A R T I C L E I N F O}

\section{Article history:}

Received 9 November 2015

Received in revised form 17 March 2016

Accepted 20 March 2016

Available online 24 March 2016

\section{Keywords:}

Bioelectrochemical systems (BES)

Anaerobic digestion

Ammonia recovery

Raw and digested pig slurry

Desulfuromonadaceae

System integration

\begin{abstract}
A B S T R A C T
Both raw and anaerobically digested pig slurries were investigated in batch assays in two chambered bioelectrochemical systems (BES) run in Microbial Fuel Cell (MFC) and Microbial Electrolysis Cell (MEC) mode. Chemical Oxygen Demand (COD) removal, nitrogen recovery, cation transport and anode microbial population evolutions were assessed. The Anaerobic Digestion-MEC (AD-MEC) integrated system achieved the highest COD removal (60\% in $48 \mathrm{~h}$ ); while the maximum $\mathrm{NH}_{4}^{+}$removal efficiency (40\%, with an ammonia flux of

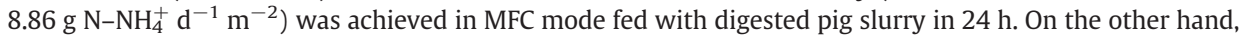
the high $\mathrm{pH}$ (12.1) achieved in $\mathrm{MEC}$ mode ( $\mathrm{NaCl}$ solution as catholyte), could favour ammonium recovery in a subsequent stripping and absorption process. Ammonia was the main cation involved in maintaining the electroneutrality between both compartments. Regarding microbial population, Desulfuromonadaceae, a known family of exoelectrogenic bacteria, was enriched under MEC mode, whereas hydrogenotrophic and methylotrophic methanogen phylotypes belonging to Thermoplasmatales were also favoured against acetotrophic Methanosaetaceae. From these results, the integration of anaerobic digestion in BES seems to be an interesting alternative for the treatment of complex substrates, since a polished effluent can be obtained and ammonium can be simultaneously recovered for further reuse as fertilizer.
\end{abstract}

(c) 2016 Elsevier B.V. All rights reserved.

\section{Introduction}

The increasing global demand for fossil fuels, their tendency to be scarcer, and the need to control the greenhouse effect gases produced when using them, are demanding new strategies for energy production. Biorefineries aiming to obtain clean and renewable energy recovering nutrients and other products of interest from energetic cultures, organic wastes and other waste fluxes are an alternative to conventional refineries [1]. Anaerobic digestion (AD), which consists in the microorganism catalysed conversion of organic substrates into a mixture of gases (biogas) - mainly methane and carbon dioxide - is a well-established energy recovering technology in terms of performance and economic feasibility and one of the most attractive technologies to produce sustainable energy from wastes [2]. However, this technology does not modify the total content of $\mathrm{N}$ in the digestates, and thus needs to be combined with other processes for $\mathrm{N}$ removal or recovery. The combination of the $\mathrm{AD}$ process with ammonia stripping with its subsequent absorption in an acid solution [3,4], thermal concentration of the digestate $[5,6]$ or chemical precipitation of ammonium and phosphate as struvite [7] has previously been studied, but despite these combined processes being feasible, few full scale applications exist nowadays.

\footnotetext{
* Corresponding author.

E-mail address: august.bonmati@irta.cat (A. Bonmatí).
}

Bioelectrochemical systems (BES) operated in microbial fuel cell (MFC) mode, or microbial electrolysis cell (MEC) mode - when electric energy is produced or energy is supplied to promote non spontaneous reactions, respectively - can also be coupled to $\mathrm{AD}$ in order to improve its performance and the quality of the effluent [8]. These systems have revealed themselves to be a highly versatile technology allowing for the coupling of wastewater treatments to the production of chemical compounds and energy carriers [9].

A wide range of complex substrates have been studied as possible energy sources for BES, such as domestic [10], slaughterhouse [11], or swine [12] wastewater, or anaerobic digester sludge [13]. The compatibility between the influent of a BES and the AD effluent makes both MFC and MEC operation suitable as a polishing step once the AD process has ended, or as a system to absorb organic compound peaks should any operational problems in the $\mathrm{AD}$ reactor arise.

In a two chamber BES with a cation exchange membrane configuration, electrons produced during the oxidation of organic matter in the anode chamber are conducted through an external circuit to the cathode; as a result, and in order to maintain charge electroneutrality between both compartments, protons produced in the anode as a result of organic matter oxidation diffuse through the cation exchange membrane to the cathode compartment, where, for instance, they are combined with oxygen to produce molecular water. However, other cations, such as ammonia, are usually present in the anode compartment in a higher concentration than protons (typically $10^{5}$ times) and 
are the predominant species involved in maintaining the charge balance, resulting in a $\mathrm{pH}$ gradient between anolyte and catholyte [14]. This fact can be exploited to remove or recover nutrients, such as ammonium, from waste flux. There are some experiences focused on removing ammonia from the cathode compartment using different configurations [15], and even simultaneous nitrification and denitrification processes through intermittent aeration of the cathode have been achieved [16]. The possibility of recovering ammonium from the cathode compartment adding a subsequent step of stripping and absorption [17-20] to later reuse it as a cleaner fertilizer, is especially interesting since nutrient recovery is favoured instead of nutrient removal and fertilizer production from raw materials.

Despite this previous work, performed in a synthetic medium, swine wastewater or urine, there is a lack of comprehensive studies focused on chemical oxygen demand (COD) and ammonia removal from complex waste flux in BES when treating digestates compared with the treatment of the raw substrates, to be able to evaluate if the AD-BES combination is a suitable treatment strategy. Furthermore, an analysis of the microbial population that develops in the anode of the BES is also needed to better understand its performance when working with digestates in different operational modes (MFC and MEC).

In the present study, BES operation in combination with AD was investigated in batch assays in order to improve COD removal and nitrogen recovery from a complex waste substrate such as pig slurry, compared to raw pig slurry treatment in BES. Furthermore, charge production, its relation with cation transport through the membrane and the influence of the other cations on the ammonium migration flux was also assessed. Finally, the evolution of microbial populations (total eubacteria and archaea) on the anode biofilm, both under MFC and MEC operation mode, was studied to identify potential key players involved in electric current production.

\section{Materials and methods}

\subsection{Experimental set-up}

A pair of identical two chambered cells were constructed in methacrylate, with the anode and cathode compartments $\left(0.14 \times 0.12 \times 0.03 \mathrm{~m}^{3}\right)$ separated by a cation exchange membrane (CEM) (dimensions: $14 \times 12 \mathrm{~cm}$; Ultrex CMI-7000, Membranes International Inc., Ringwood, NJ, USA). A carbon felt was used as anode (dimensions: $14 \times 12 \mathrm{~cm}$; thickness: $3.18 \mathrm{~mm}$; Alfa Aesar GmbH \& Co KG, Karlsruhe, Germany); and a 304 stainless steel mesh was used as cathode (dimensions: $14 \times 12 \mathrm{~cm}$; mesh width: $150 \mu \mathrm{m}$; wire thickness: $112 \mu \mathrm{m}$; Feval Filtros, Spain). Prior to its use, and in order to remove all impurities from the carbon felt, it was sequentially soaked in acetone and nitric acid for $3 \mathrm{~h}$ and later rinsed in deionized water, as elsewhere described [21]. An $\mathrm{Ag} / \mathrm{AgCl}$ reference electrode (Bioanalytical Systems, Inc., USA) was inserted in the anode compartment (+197 mV vs. SHE (all potential values hereafter in this paper are referred to SHE)). The anode of each cell was connected to the cathode through a potentiostat (VSP, Bio-Logic, Grenoble, France) in a three electrode mode for data monitoring and poising of the anode potential (working electrode) when operating in MEC mode. The potentiostat was connected to a personal computer which recorded electrode potentials and current densities every 5 min using EC-Lab software V10.32 (Bio-Logic, Grenoble, France).

The anodic chamber of each cell was inoculated with a $30 \mathrm{~mL}$ (volatile suspended solids content of $2 \mathrm{~g} \mathrm{~L}^{-1}$ ) resuspension of a MFC anode biofilm which had been operated with raw pig slurry [20] and was stored submerged in pig slurry at $+4{ }^{\circ} \mathrm{C}$ for 2 months. The resuspension was done by vortex mixing during $10 \mathrm{~min}$ in a $50 \mathrm{~mL}$ tube containing $10 \mathrm{~cm}^{2}$ of the carbon felt used as anode and $35 \mathrm{~mL}$ of Ringer $1 / 4$ sterilized solution. Two feedings were used in the anode compartment: i) raw pig slurry, and ii) digested pig slurry obtained from a thermophilic $\left(55^{\circ} \mathrm{C}\right) 2 \mathrm{~L}$ lab-scale continuous stirred tank reactor. Both the raw pig slurry and the effluent of the AD were sieved to remove particles larger than $125 \mu \mathrm{m}$ previous to being used as feed for the BES (Table 1). The feeding solution for the MFC cathode chamber contained (per litre of deionized water): $\mathrm{KH}_{2} \mathrm{PO}_{4}, 3 \mathrm{~g}$; and $\mathrm{Na}_{2} \mathrm{HPO}_{4}, 6$ g. Aerobic conditions were maintained in the cathode (MFC) supplying air at a flow rate of $2 \mathrm{~L} \mathrm{~min}^{-1}$. The catholyte for the MEC consisted of $\mathrm{NaCl} 0.1 \mathrm{~g} \mathrm{~L}^{-1}$. Both the anode and the cathode compartment solutions were mixed continuously recirculating them with an external pump.

\subsection{Reactors operation}

The AD was fed in continuous mode with the raw pig slurries previously specified (Table 1 ) with a hydraulic retention time (HRT) fixed at $5 \mathrm{~d}$, and an organic loading rate (OLR) of $2.26 \mathrm{~g} \mathrm{COD} \mathrm{L}^{-1} \mathrm{~d}^{-1}$. The reactor ran for 3 months and, once the steady state of operation regarding COD removal and biogas production was achieved, the effluent of the AD was collected during 3 weeks and homogenized in order to be used as substrate for the BES (hereafter referred to as digested pig slurry). The digested pig slurry was stored at $-20^{\circ} \mathrm{C}$ for further utilization. Samples of the BES substrate were taken in every experimental run to assure that its characteristics remained stable.

The MFC was operated under six different conditions (Table 2). In the first three assays, raw pig slurry was used as feeding, and the MFC was operated using two different external resistances (100 $\Omega$ and $500 \Omega$ ) and in open circuit to investigate diffusion driven processes. In the second set of assays, digested pig slurry was used as feeding. The MEC was operated under eight different conditions (Table 2), fixing the anode potential at $-200,-100$ and $0 \mathrm{mV}$ vs. SHE, and in open circuit, using raw pig slurry in the first stage, and later repeating the same conditions with digested pig slurry. Both cells were operated at room temperature $\left(\sim 23-25^{\circ} \mathrm{C}\right)$.

Prior to every experimental run, the anode and the cathode compartment of each cell were filled with $0.5 \mathrm{~L}$ of the correspondent solution and emptied completely at the end of each run; repeating this procedure every $24 \mathrm{~h}$ and $48 \mathrm{~h}$ in the MFC and the MEC (according to the duration of the current density peaks in each mode), respectively, in order to perform three batches for every condition. Samples were taken from the anode and the cathode compartment at different times during the run - three samples for the MFC experiments, and four samples for the MEC experiments.

Table 1

Characterization of raw and digested pig slurry used as feedings in the AD and the BES. Abbreviations: MFC: microbial fuel cell, MEC: microbial electrolysis cell, AD: anaerobic digestion, COD: chemical oxygen demand, $\mathrm{N}-\mathrm{NH}_{4}^{+}$: ammonium nitrogen, TS: total solids, VS: volatile solids.

\begin{tabular}{|c|c|c|c|}
\hline \multirow{2}{*}{ Parameter } & \multirow{2}{*}{$\begin{array}{l}\begin{array}{l}\text { AD reactor } \\
\text { feeding }\end{array} \\
\begin{array}{l}\text { Raw pig } \\
\text { slurry }\end{array}\end{array}$} & \multicolumn{2}{|c|}{ MEC/MFC feeding } \\
\hline & & $\begin{array}{l}\text { Raw pig slurry } \\
\text { (sieved } 125 \mu \mathrm{m} \text { ) }\end{array}$ & $\begin{array}{l}\text { Digested pig slurry } \\
\text { (sieved } 125 \mu \mathrm{m} \text { ) }\end{array}$ \\
\hline $\mathrm{pH}(-)$ & 7.98 & 7.98 & 8.12 \\
\hline Alkalinity $\left(\mathrm{g}_{\mathrm{CaCO}_{3}} \mathrm{~L}^{-1}\right)$ & 3.5 & 3.5 & 3.6 \\
\hline $\operatorname{COD}\left(\mathrm{mg}_{\mathrm{O}_{2}} \mathrm{~kg}^{-1}\right)$ & 14585 & 6512 & 7951 \\
\hline $\mathrm{N}-\mathrm{NH}_{4}^{+}\left(\mathrm{mg} \mathrm{L}^{-1}\right)$ & 997 & 857 & 872 \\
\hline TS (\%) & 1.74 & 0.78 & 0.83 \\
\hline VS (\%) & 1.04 & 0.37 & 0.42 \\
\hline $\mathrm{NH}_{4}^{+}\left(\mathrm{mg} \mathrm{L}^{-1}\right)$ & & 1102 & 1121 \\
\hline $\mathrm{NH}_{4}^{+}(\mathrm{mM})$ & & 61.2 & 62.3 \\
\hline $\mathrm{Na}^{+}\left(\mathrm{mg} \mathrm{L}^{-1}\right)$ & & 359 & 383 \\
\hline $\mathrm{Na}^{+}(\mathrm{mM})$ & & 15.6 & 16.7 \\
\hline $\mathrm{Mg}^{2+}\left(\mathrm{mg} \mathrm{L}^{-1}\right)$ & & 14 & 9 \\
\hline $\mathrm{Mg}^{2+}(\mathrm{mM})$ & & 0.6 & 0.4 \\
\hline $\mathrm{Ca}^{2+}\left(\mathrm{mg} \mathrm{L}^{-1}\right)$ & & 3272 & 3219 \\
\hline $\mathrm{Ca}^{2+}(\mathrm{mM})$ & & 81.8 & 80.5 \\
\hline $\mathrm{K}^{+}\left(\mathrm{mg} \mathrm{L}^{-1}\right)$ & & 1093 & 1045 \\
\hline $\mathrm{K}^{+}(\mathrm{mM})$ & & 28.0 & 26.8 \\
\hline $\mathrm{PO}_{4}^{3-}\left(\mathrm{mg} \mathrm{L}^{-1}\right)$ & & 9713 & 8315 \\
\hline $\mathrm{PO}_{4}^{3-}(\mathrm{mM})$ & & 102.2 & 87.5 \\
\hline
\end{tabular}


Table 2

Conditions tested in MFC and MEC operation modes. Abbreviations: MFC: microbial fuel cell, MEC: microbial electrolysis cell, OCV: open circuit voltage.

\begin{tabular}{|c|c|c|c|}
\hline Operation mode & Catholyte & Feeding & $\begin{array}{l}\mathrm{R}_{\text {ext }}(\Omega)(\mathrm{MFC} \text { mode) } \\
\mathrm{E}_{\text {anode }}(\mathrm{mV})(\mathrm{MEC} \text { mode) }\end{array}$ \\
\hline \multirow[t]{7}{*}{ MFC } & \multirow{7}{*}{$\begin{array}{l}\text { Phosphate buffer } \\
\text { solution }\end{array}$} & \multirow[t]{3}{*}{ Raw pig slurry } & 100 \\
\hline & & & 500 \\
\hline & & & $\mathrm{OCV}$ \\
\hline & & \multirow[t]{4}{*}{ Digested pig slurry } & 100 \\
\hline & & & 500 \\
\hline & & & $\mathrm{OCV}$ \\
\hline & & & $\mathrm{OCV}$ \\
\hline \multirow[t]{8}{*}{ MEC } & \multirow[t]{8}{*}{$\mathrm{NaCl}$ solution } & \multirow{4}{*}{ Raw pig slurry } & -200 \\
\hline & & & -100 \\
\hline & & & 0 \\
\hline & & & $\mathrm{OCV}$ \\
\hline & & \multirow[t]{4}{*}{ Digested pig slurry } & -200 \\
\hline & & & -100 \\
\hline & & & 0 \\
\hline & & & $\mathrm{OCV}$ \\
\hline
\end{tabular}

\subsection{Analytical methods and calculations}

Chemical oxygen demand (COD), ammonium $\mathrm{N}-\mathrm{NH}_{4}^{+}$, alkalinity (Alk) and $\mathrm{pH}$, were analysed according to Standard Methods 5220 [22]. The $\mathrm{pH}$ of the bulk solution in each experiment was measured using a CRISON $2000 \mathrm{pH}$ electrode. Anion concentration $\left(\mathrm{Cl}^{-}, \mathrm{NO}_{3}^{-}\right.$, $\mathrm{NO}_{2}^{-}, \mathrm{PO}_{4}^{3-}, \mathrm{SO}_{4}^{2-}$ ) were measured by ionic chromatography (IC) by a 861 Advanced Compact IC (Metrohm, Switzerland) using a Metrosep A Supp 4-250 (Metrohm, Switzerland) column and a $\mathrm{CO}_{2}$ suppressor. Cations $\left(\mathrm{Na}^{+}, \mathrm{K}^{+}, \mathrm{Ca}^{+2}, \mathrm{Mg}^{+2}\right)$ were also measured by a 790 Personal IC (Metrohm, Switzerland) and Metrosep C2 column (Metrohm, Switzerland). Prior to the IC analysis, samples were diluted and filtrated with nylon $(0.45 \mathrm{~mm})$ and BonElut JR C18 micro filters (Varian, USA). Ammonium (N-NH${ }_{4}^{+}$) was analysed by a Büchi B-324 distiller (Büchi Labortechnik AG, Switzerland), and a Metrohm 702 SM autotitrator (Metrohm, Switzerland). Volatile fatty acids (VFAs) were quantified using a VARIAN CP-3800 (Varian, USA) gas chromatograph equipped with flame ionization detector (FID).

Methane production in the BES was calculated through the determination of dissolved methane in solution [23]. Around $2.5 \mathrm{~mL}$ anolyte samples were collected with a $5 \mathrm{~mL}$ syringe and injected with a needle in a $5 \mathrm{~mL}$ vacutainer. The vacutainers were shaken vigorously for $30 \mathrm{~s}$ and then allowed to stand for $1 \mathrm{~h}$. Headspace gas was analysed for $\mathrm{CH}_{4}$ using a VARIAN CP-3800 (Varian, USA) gas chromatograph. Dissolved $\mathrm{CH}_{4}$ was computed using the equation:

$X_{L}=\frac{C_{C_{4}} \cdot M V_{C_{4}} \cdot M W_{C_{4}} \cdot\left(V_{T}-V_{L}+\alpha V_{L}\right) \cdot 1000}{V_{L}}$

where $X_{L}$ is the concentration of $\mathrm{CH}_{4}\left(\mathrm{mg} \mathrm{L}^{-1}\right)$ in the solution, $\mathrm{C}_{\mathrm{CH} 4}$ is the concentration of $\mathrm{CH}_{4}(\%)$ in the headspace $1 \mathrm{~h}$ after shaking, $M V_{C H 4}$ is the molar volume of $\mathrm{CH}_{4}$ at $25^{\circ} \mathrm{C}\left(0.041 \mathrm{~mol} \mathrm{~L}^{-1}\right), \mathrm{MW}_{\mathrm{CH}}$ is the molecular weight of $\mathrm{CH}_{4}\left(16 \mathrm{~g} \mathrm{~mol}^{-1}\right), V_{T}$ is the volume $(\mathrm{mL})$ of the vacutainer, $V_{L}$ is the volume ( $\mathrm{mL}$ ) of the solution, and $\alpha$ is the water: air partition coefficient at $25{ }^{\circ} \mathrm{C}(0.03)$.

Current density, $j\left(\mathrm{~A} \mathrm{~m}^{-2}\right)$ was obtained according to $j=V /(R \cdot a)$, where $V(\mathrm{~V})$ is the cell voltage, $R(\Omega)$ is the resistance and $a\left(\mathrm{~m}^{2}\right)$ is the area of the anode in contact with the anode bulk solution. Coulombic efficiency, CE, based on current generation and the COD removal amount during BES operation, was calculated as:

$\mathrm{CE}=\frac{M \int_{0}^{t} I d t}{\mathrm{~F} \cdot \mathrm{b} \cdot V_{\mathrm{an}} \cdot \Delta \mathrm{COD}}$ where $M$ is the molecular weight of the final electron acceptor, $I$ is the current (A), $F$ is Faraday's constant $\left(96,485 \mathrm{C} \mathrm{mol}^{-1}\right), b$ is the number of electrons transferred per mole of $\mathrm{O}_{2}, V_{a n}$ is the volume of the anode compartment and $\triangle C O D$ is the change in COD in the time $t(\mathrm{~h})$.

$\mathrm{CH}_{4}$ production efficiency was calculated as the ratio between the COD contained in the $\mathrm{CH}_{4}$ and the total removed COD. Ammonium removal efficiency was calculated as the ratio of the difference between initial and final concentrations in the bulk solution in each batch assay and its initial concentration. The flux of $\mathrm{N}-\mathrm{NH}_{4}^{+}$from the anode to the cathode ( $\mathrm{g} \mathrm{N}-\mathrm{NH}_{4}^{+} \mathrm{d}^{-1} \mathrm{~m}^{-2}$ ) was calculated as the difference between the initial and final concentration, divided by the volume of the anode compartment, the time of the batch (day) and the surface of the cationic exchange membrane $\left(\mathrm{m}^{2}\right)$.

When calculating charge, $\mathrm{Q}$ a distinction was made between transport of negative charges in the form of electrons through the electric circuit, $\mathrm{Q}^{-}$, and transport of positive charges in the form of the dominantly present cation species in the system $\left(\mathrm{Na}^{+}, \mathrm{K}^{+}, \mathrm{NH}_{4}^{+}, \mathrm{Ca}^{2+}\right.$, and $\left.\mathrm{Mg}^{2+}\right)$, through the membrane, $\mathrm{Q}^{+}$. Total charge production, $\mathrm{Q}^{-}$, expressed in coulombs $(C)$ was determined by integrating current over time. Transport of positive charges in the form of cation species in the system through the membrane, $Q^{+}$, expressed in coulombs $(C)$ was determined as follows:

$\mathrm{Q}^{+}=\sum_{\text {cat }}\left(\left(x^{\mathrm{cat}, t}-x^{\mathrm{cat}, 0}\right) \mathrm{V} \cdot \mathrm{z}^{\mathrm{cat}} \cdot F\right)$

with $x^{\text {cat,t }}$ the molar concentration of the cation species at the end of an experimental run expressed in $\mathrm{mol} \mathrm{L}^{-1}(\mathrm{M}), x^{\text {cat,o }}$ the molar concentration of the cation species at the start of an experimental run expressed in $\mathrm{mol} \mathrm{L}^{-1}(\mathrm{M}), V$ the cathode chamber liquid volume expressed in litres $(\mathrm{L}), z^{\text {cat }}$ the valence of the cation species, and $F$ the Faraday constant $\left(96,485 \mathrm{C} \mathrm{mol}^{-1}\right)$.

Data were analysed using one-way analysis of variance (ANOVA). Whenever significant differences of means were found, the Tukey test at a $5 \%$ significance level was performed for separation of means. Statistical analysis was performed using the R software package ( $R$ project for statistical computing, http://www.r-project.org).

\subsection{Microbial community analysis}

To determine the effect the shift from MFC to MEC mode had on the microbial population (total eubacteria and archaea) harboured on the anode, bacterial communities present in the feedings (raw and digested pig slurry) and attached to the anode under MFC and MEC mode at the end of the experiments (after 2 and 4 months of operation, respectively) were analysed by 454-Pyrosequencing. Total DNA was extracted in triplicate from known weights of each sample following a bead-beating protocol by means of the PowerSoil ${ }^{\circledR}$ DNA Isolation Kit (MoBio Laboratories Inc., Carlsbad, CA, USA), according to the manufacturer's instructions. The specific steps for eubacteria and archaea 454Pyrosequencing analysis were carried out as follows: Massive barcoded $16 \mathrm{~S}$ rRNA gene libraries, targeting eubacterial region V1-V3 165 rRNA and archaeal region V3-V4, were sequenced using the 454 FLX Titanium (Roche Diagnostics, Branford, CT, USA) equipment. In summary, diluted DNA extracts (1:10) were used as a template for PCR. Each DNA (two independent total DNA extracts per sample) was amplified separately with both the eubacteria and archaea $16 \mathrm{~S}$ rRNA set of primers containing unique multiplex identifier (MID) tags recommended by Roche Diagnostics (Roche Diagnostics, 2009). For eubacteria libraries the primer sets were 27F ( $5^{\prime}$-AGRGTTTGATCMTGGCTCAG-3') and 519R ( $5^{\prime}$-GTNTTACNGCGGCKGCTG-3'), while the archaeal sets of primers were $349 \mathrm{~F}$ (5'-GYGCASCAGKCGMGAAW-3') and 806R (5'GGACTACVSGGGTATCTAAT-3'). PCR conditions, subsequent purification and 454-pyrosequencing steps were performed as elsewhere described [24].

Downstream 454-Pyrosequencing data analysis was carried out using QIIME software version 1.8.0 [25] following a trimming protocol 
and grouping into Operational Taxonomic Units (OTUs) as previously described [24]. The obtained OTUs were taxonomically classified using the Bayesian Classifier database of the Ribosomal Database Project (RDP) V11 [26]. Data obtained from pyrosequencing datasets were deposited in the sequence read archive of the National Center for Biotechnology Information (NCBI) under study accession number SRP062261, for eubacterial and archaeal populations.

To evaluate the diversity of the samples, the number of OTUs, the inverted Simpson index, Shannon index, Goods coverage and Chao1 richness estimator were calculated using Mothur software v.1.34.4 (http://www.mothur.org) [27]. All estimators were normalized to the lower number of reads among the different samples. Statistical multivariate analyses (covariance-based Principal Component Analyses (PCA) and correspondence analysis (CA)) of the pyrosequencing data were performed by means of the XLSTAT 2014 software (Addinsoft, Paris, France).

\section{Results and discussion}

\subsection{Performance of the anaerobic digester}

The AD reactor was under operation for 118 days, reaching a steady state on day 67 . During this stable period the average COD removal efficiency was of $40 \%$, with a final COD of $8858 \mathrm{mg} \mathrm{O}_{2} \mathrm{~kg}^{-1}, 869 \mathrm{mg} \mathrm{N}-\mathrm{NH}_{4}^{+}$ $\mathrm{L}^{-1}, 48 \mathrm{mg}$ acetic acid $\mathrm{L}^{-1}$ and a $\mathrm{pH}$ of 7.9. The methane content of the produced biogas was of $72 \%$ of $\mathrm{CH}_{4}$.

\subsection{Performance of the BES}

3.2.1. Current density and removal efficiencies of the MFC batch experiments

The profiles of the current density generated, and the COD and ammonium removal efficiencies corresponding to the three batches performed in MFC mode with an external resistance of $100 \Omega$ are shown in Fig. $1 \mathrm{a}$ and $\mathrm{b}$. As it can be seen, the response of the three batches was very similar, achieving $250 \mathrm{~mA} \mathrm{~m}^{-2}$ and $225 \mathrm{~mA} \mathrm{~m}^{-2}$ peak current densities, when respectively fed with raw and digested pig slurry. Similar results were obtained using an external resistance of $500 \Omega$ (data not shown); although in this case the maximum current densities were 70 and $60 \mathrm{~mA} \mathrm{~m}^{-2}$, respectively. These current densities are in the same range as in other studies that also used swine wastewater in a MFC [12]. As expected, the current density decreased with respect to the increasing external resistance according to Ohm's law. Interestingly, although COD removal started in the first hours and continued for more than $24 \mathrm{~h}$, current generation became minimal $10 \mathrm{~h}$ after fresh substrate addition, as less biodegradable organic matter may be available. This behaviour was also observed when studying COD removals in a single chamber MFC treating domestic wastewater with a soluble COD of $223 \mathrm{mg} \mathrm{L}^{-1}$ [28]. In that study, graphite fibre brush was used as anode, and the applied external resistances were $1000 \Omega$ and $100 \Omega$.

Results of the MFC operation (Fig. 2a and b) showed that there were no statistically significant differences in COD removal when working with an open or closed circuit (17-21\% and $7-12 \%$ with raw and digested pig slurry, respectively). These data indicate that microorganisms attached to the anode or in suspension may be using final electron acceptors present in the medium. Lower COD removals when using digested pig slurry can be expected, as organic matter present in the effluent of an $\mathrm{AD}$ can be less biodegradable. A decrease in COD removal was also reported when changing from raw to digested primary sludge [13]. Nevertheless, if the integrated AD-MFC system is taken into account, the overall COD removal efficiency would be of around 50\% (final average COD of $7160 \mathrm{mg} \mathrm{O}_{2} \mathrm{~kg}^{-1}$ ). Furthermore, almost all ammonium transport produced in this MFC is promoted by diffusion, probably due to the low current densities achieved, with removal efficiencies of $32-35 \%$ and $32-40 \%$ for raw and digested pig slurry, respectively. This a)

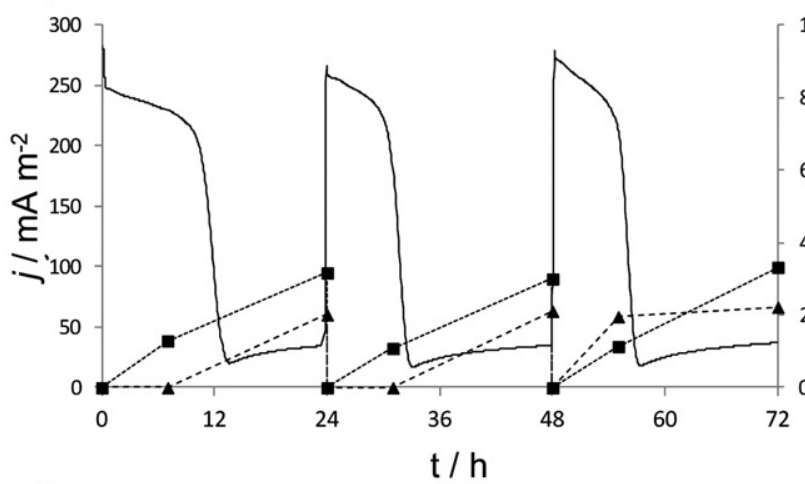

c)
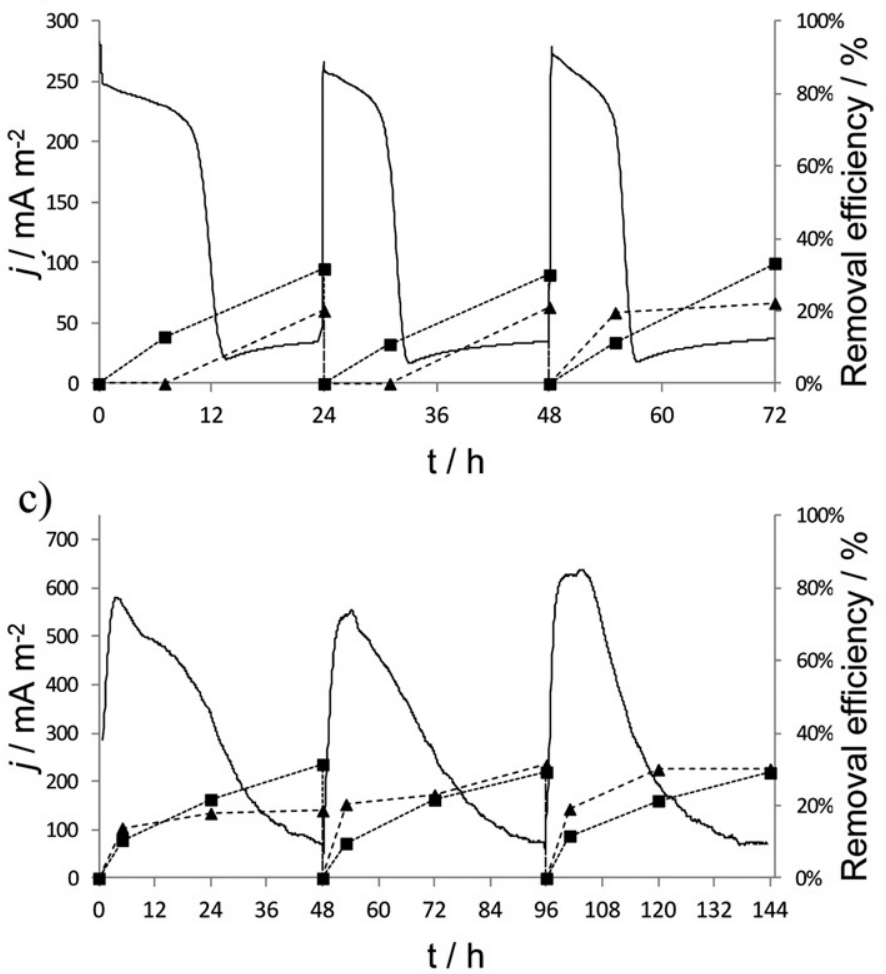

b)

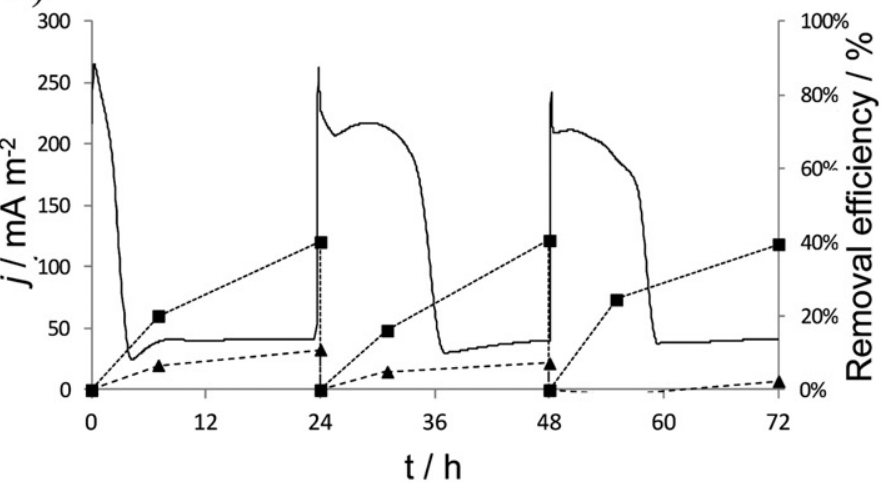

d)

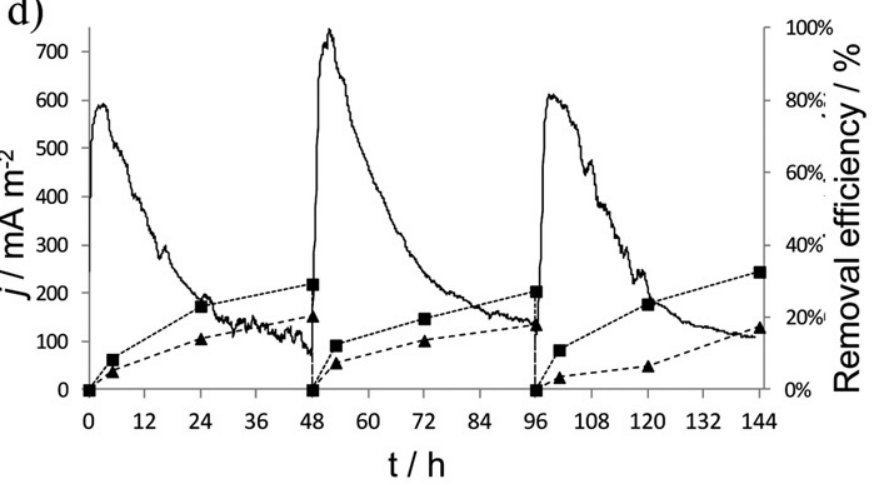

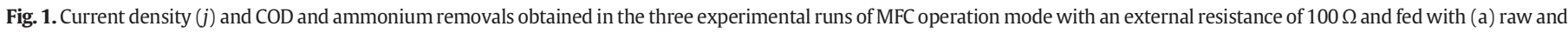

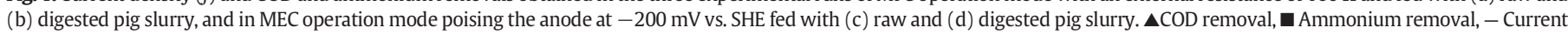
density. 
a)
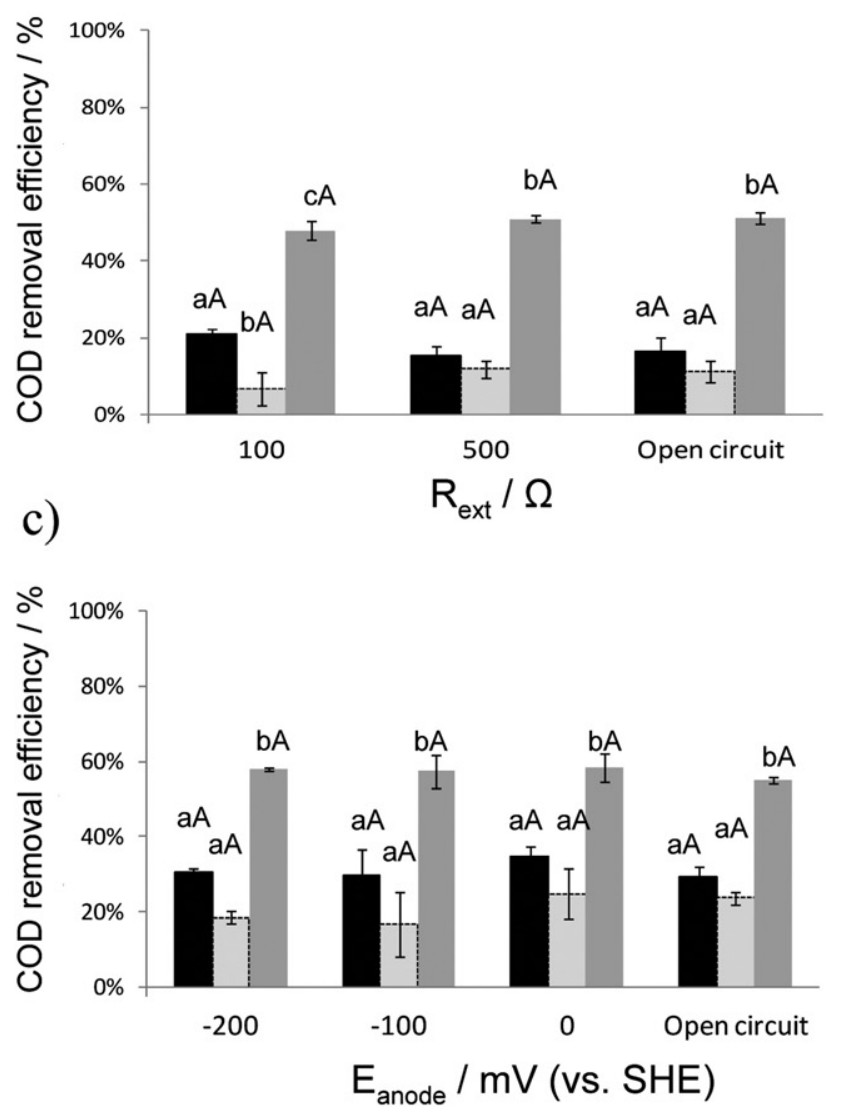

b)
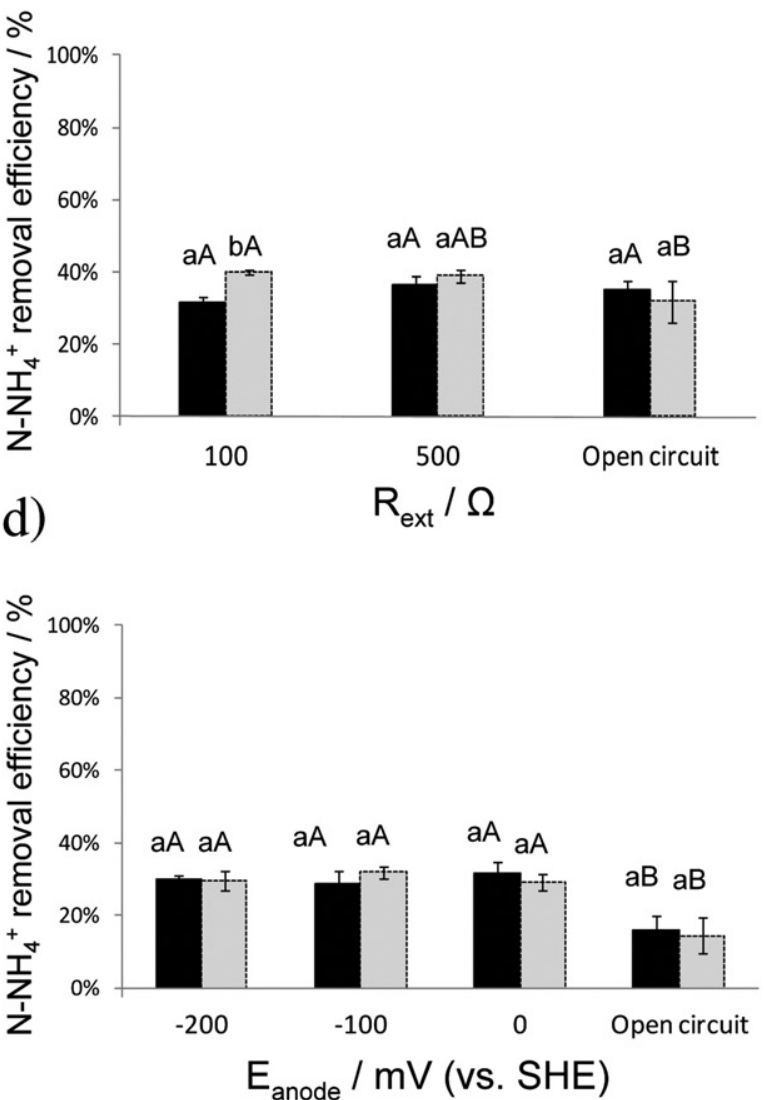

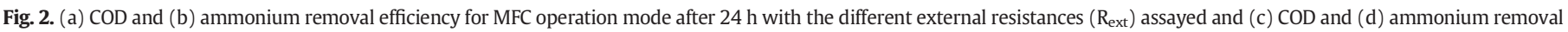

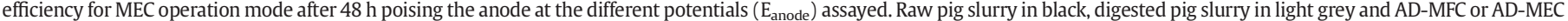

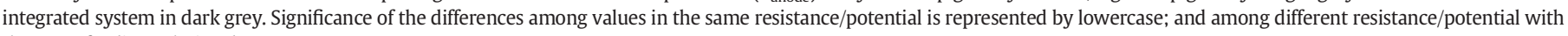
the same feeding solution, by uppercase.

behaviour was also observed by Kuntke at al. [19], who reported that, at low current densities, ammonia diffusion was the dominant ammonium transport mechanism. Zhang et al. [15] also reported high ammonium diffusion in their system in batch mode when no voltage was applied, achieving $30 \%$ when working with a synthetic solution.

Initial $\mathrm{pH}$ of the raw pig slurry was in a range of 7.9-8.1, a result which is very similar to the final $\mathrm{pH}$ range of 7.8-8.2. In the case of the catholyte, the initial $\mathrm{pH}$ of 7.1 was maintained at the end of each batch. For digested pig slurry, the initial $\mathrm{pH}$ of 8.1-8.2 remained in a range of 7.9-8.3 at the end of the assays. Regarding the catholyte, it remained around 7.3. These stable values are explained because a buffer phosphate was being used as a catholyte.

\subsubsection{Current density and removal efficiencies of the MEC batch experiments}

The profiles of the generated current density and COD and ammonium removal efficiencies corresponding to the three sequential batches performed in MEC mode poising the anode at $-200 \mathrm{mV}$ vs. SHE, using raw and digested pig slurry are shown in Fig. 1c and d, respectively. The MEC showed maximum current densities of 600,750 and $700 \mathrm{~mA} \mathrm{~m}^{-2}$ poising the anode at $-200,-100$ and $0 \mathrm{mV}$ vs. SHE, respectively, when it was fed with raw pig slurry; similar results for the three sequential batches were achieved when it was fed with digested pig slurry (data not shown). There were no statistically significant differences in COD removal when working with an open or closed circuit, neither when feeding with raw nor digested pig slurry (29-35\% and 17$25 \%$ respectively), but an overall COD removal of nearly $60 \%$ was achieved in combination with the AD (final average COD of $6080 \mathrm{mg}$
$\mathrm{O}_{2} \mathrm{~kg}^{-1}$ ) (Fig. 2c). Ammonium removal was maximum when feeding with raw pig slurry and poising the anode potential at $0 \mathrm{mV}$ vs. SHE ( $31 \%$, with a final $\mathrm{N}-\mathrm{NH}_{4}^{+}$of $606 \mathrm{mg} \mathrm{L}^{-1}$ ), two-fold higher than the ammonium transferred from the anode to the cathode compartment in an open circuit mode (16\%) (Fig. 2d). Ammonia diffusion values in an open circuit are similar to those obtained in other studies, with a $13 \%$ achieved in batch assays lasting $120 \mathrm{~h}$ with a synthetic solution [29]. The same study achieved a 2.5 fold increase when the anode potential was fixed at $-0.2 \mathrm{~V} v$ s. SHE. Also around $30 \%$ of ammonia was recovered in continuous assays fed with urine [30] and $29 \%$ of ammonia was recovered in $56 \mathrm{~h}$ batch assays using pig slurry as anolyte and a $\mathrm{NaCl}$ solution in the cathode when applying $0.6 \mathrm{~V}$ to an abiotic two-chamber cell [20]. The same study showed that ammonia recovering was improved by using a $\mathrm{NaCl}$ solution instead of a buffer in the cathode, even in an open circuit, reaching removal efficiencies of $50 \%$.

Contrary to the behaviour observed in MFC mode, $\mathrm{pH}$ evolution in the assays fed with raw pig slurry showed a decreasing tendency during the assay, achieving a final $\mathrm{pH}$ in the range of 7.0-7.3, except in the open circuit assays, were $\mathrm{pH}$ was maintained around 8 . In the case of the catholyte, $\mathrm{pH}$ increased from 9.1 to around $10.8-12.1$ at the end of the batches, and remained under 10 in open circuit assays, as a $\mathrm{NaCl}$ instead of a buffer solution was used. For digested pig slurry, the final $\mathrm{pH}$ in the anode and cathode compartments showed similar values to the ones obtained with raw pig slurry, both in a closed and open circuit. In spite of anodic acidification due to cation transport to the cathode compartment and proton accumulation in the anode, $\mathrm{pH}$ was still suitable for microorganism growth, thanks to the buffering capacity of the pig slurry. On the other hand, the high $\mathrm{pH}$ achieved in the cathode 
compartment is highly convenient for ammonia recovering, since it can drive ammonium to ammonia gas favouring a subsequent stripping and absorption process [20].

To sum up, the results revealed that COD removal was improved by integrating $\mathrm{AD}$ and $\mathrm{BES}$ technologies and, furthermore, ammonia content of the $\mathrm{AD}$ effluent can be recovered and could maybe be reused as an alternative fertilizer, integrating a stripping and absorption unit in the system.

\subsubsection{Coulombic efficiency and methane production}

Coulombic and methane production efficiencies are shown in Table 3. Assays in MEC mode presented higher CE than in MFC mode, with a maximum of $18 \%$ and, in both operation modes, the highest CEs were achieved when digested pig slurry was used. Furthermore, in MFC mode, higher CEs were achieved when the lowest external resistance was applied. Other studies have reported that, in general, CE was a function of substrate concentration and circuit resistance, and an increasing circuit resistance or substrate concentration results in a decrease in $\mathrm{CE}$, because it is difficult to recover electrons from substrates with higher external resistances [28]. The thus obtained CEs are quite low, but this is to be expected as the feedings are complex substrates and other electron acceptors may be present. Other studies have shown similar CEs with complex substrates, reporting a CE range of 3$12 \%$ using local domestic wastewater as substrate [10], 8\% using swine wastewater in a single chambered MFC [12], or a range of $12-18 \%$ using digestate from grass silage in a MFC [31]. Interestingly, the MFC displayed a higher methane production than the MEC, and accumulated methane, though it only accounted for $1 \%$ of COD removal in MEC mode, this being lower than data previously described [32]. The percentage of COD removal converted to methane increased up to 3-7\% in MFC mode. The highest methane production in MFC mode may be related to the lower potentials of the anode in the MFC $(<-300 \mathrm{mV})$ with respect to the MEC, since a previous study found that the lower the anode potential the higher the methane production [33]. Furthermore, methane production slightly increased in the MEC mode as the fixed anode potential was decreased, although the differences found were not statistically significant.

\subsubsection{Charge and cation transfer}

It is well known that the flux through a membrane can be the result of diffusion (caused by a concentration gradient) or migration (caused by the charge transport and balance) $[14,34]$. Comparison of the total charge production in the form of electrons relative to the transport of charge in the form of cations through the cationic membrane of each condition assayed is shown in Fig. 3. In the case of the MFC operation (Fig. 3a and b), since the intensities produced were quite low, the amount of electrons transferred was negligible with respect to positive charges, thus achieving approximately the same cation transport both

\section{Table 3}

Coulombic Efficiency and $\mathrm{CH}_{4}$ production efficiency obtained in the different assays. Abbreviations: CE: coulombic efficiency, MFC: microbial fuel cell, MEC: microbial electrolysis cell, $R_{\text {ext }}$ : external resistance, $E_{\text {anode }}$ : anode potential.

\begin{tabular}{|c|c|c|c|c|}
\hline $\begin{array}{l}\text { Operation } \\
\text { mode }\end{array}$ & Feeding & $\begin{array}{l}\mathrm{R}_{\text {ext }}(\Omega)(\text { MFC mode }) \\
\mathrm{E}_{\text {anode }}(\mathrm{mV})(\text { MEC mode })\end{array}$ & CE (\%) & $\begin{array}{l}\mathrm{CH}_{4} \\
\text { production } \\
\text { efficiency } \\
(\%)\end{array}$ \\
\hline \multirow[t]{4}{*}{ MFC } & Raw pig slurry & 100 & $2.2 \pm 0.4 \%$ & $7 \pm 3 \%$ \\
\hline & & 500 & $1.1 \pm 0.6 \%$ & $7 \pm 1 \%$ \\
\hline & Digested pig & 100 & $4 \pm 3 \%$ & $3 \pm 2 \%$ \\
\hline & slurry & 500 & $1.3 \pm 0.3 \%$ & $4.2 \pm 0.4 \%$ \\
\hline \multirow[t]{6}{*}{ MEC } & Raw pig slurry & -200 & $8.0 \pm 0.2 \%$ & $0.7 \pm 0.2 \%$ \\
\hline & & -100 & $9 \pm 2 \%$ & $0.3 \pm 0.1 \%$ \\
\hline & & 0 & $7 \pm 2 \%$ & $0.2 \pm 0.1 \%$ \\
\hline & Digested Pig & -200 & $12 \pm 3 \%$ & $1.0 \pm 0.1 \%$ \\
\hline & Slurry & -100 & $18 \pm 8 \%$ & $0.9 \pm 0.0 \%$ \\
\hline & & 0 & $11 \pm 3 \%$ & $0.9 \pm 0.2 \%$ \\
\hline
\end{tabular}

in an open or closed circuit. Sodium was the most transferred cation, despite it being initially found in a lower concentration in the anode than in the buffer solution of the cathode. In this study the most abundant cation was calcium (3200 $\mathrm{mg} \mathrm{L}^{-1}$ ), followed by ammonium (1100 $\mathrm{mg} \mathrm{L}^{-1}$ ) and potassium (1090 $\mathrm{mg} \mathrm{L}^{-1}$ ), being sodium the one found in less concentration $\left(360 \mathrm{mg} \mathrm{L}^{-1}\right)$. These results differ from the obtained by Kuntke et al. [34], who reported that in a MFC the order in which cations were transported corresponded to the concentration of the ions in the anode compartment $\left(\mathrm{NH}_{4}^{+} \geq \mathrm{Na}^{+}>\mathrm{K}^{+}>\mathrm{Ca}^{2+}\right.$ ${ }^{2+}>>\mathrm{Mg}^{2+}$ ). These differences can be due to the fact that a synthetic solution was used for the anode in that study and the use of different catholytes. Regarding MEC operation, Fig. $3 \mathrm{c}$ and d show a clear increase in cation transport through the membrane when applying different potentials to the system with respect to the open circuit assay. Although in the latter case there was already some cation transport, it improved in parallel to the negative charge increase, being ammonia the predominant cation involved in maintaining electroneutrality. As an example, when using digested pig slurry in MEC mode, ammonia accounted for 64,55 and $45 \%$ of the total amount of cations transferred when the anode was fixed at $0,-100$ and $-200 \mathrm{mV}$, respectively. When the amount of cations transferred in an open circuit assay was subtracted, results showed that ammonia accounted for 63,67 and $53 \%$ of the migrated positive charge when the anode was respectively fixed at $0,-$ 100 and $-200 \mathrm{mV}$. Other studies have obtained similar results, reporting that $30-50 \%$ of the charge transferred was neutralized by ammonium migration when using synthetic wastewater and real urine [29]. Sodium and potassium cations accounted for nearly the rest charge transferred when using fresh pig slurry, while calcium was favoured with respect to sodium when using the digested one. The obtained results are the consequence of the coordinated effect of a variety of driving forces. Apart from gradient concentration between both compartments, the different mobility of each cation when subjected to an electric field may have also had an impact in the obtained results. Mobility depends on the hydrodynamic radius of the ion (taking into account the hydrating water molecules it carries when moving), its charge and the viscosity of the medium. This way, $\mathrm{NH}_{4}^{+}$and $\mathrm{K}^{+}$have the same ionic mobility $\left(7.62 \cdot 10^{-8} \mathrm{~m}^{2} \mathrm{~s}^{-1} \mathrm{~V}^{-1}\right.$ in water at $\left.298 \mathrm{~K}\right)$, while $\mathrm{Na}^{+}, \mathrm{Mg}^{2+}$ or $\mathrm{Ca}^{2+}$ have lower ones $\left(5.19 \cdot 10^{-8}, 5.50 \cdot 10^{-8}\right.$ and $6.17 \cdot 10^{-8} \mathrm{~m}^{2} \mathrm{~s}^{-1} \mathrm{~V}^{-1}$, respectively) [35]. Finally, the organic matter and solids content of the raw and digested pig slurry, as well as the presence of other cations, may affect the migration patterns that have been observed with synthetic solutions. Diffusion numbers in the MFC also differ from those obtained in the MEC because of the use of different catholytes, a phosphate buffer and a $\mathrm{NaCl}$ solution, respectively. Although a higher flux was expected in MEC mode due to the concentration gradient (only $39 \mathrm{mg} \mathrm{L}^{-1}$ of sodium was present at the beginning of the batch in the cathode compartment), it was finally lower than the obtained in MFC mode using a phosphate buffer.

In summary, the results obtained show that diffusion flux was predominant in the MFC operation because of the low generated intensities while migration promoted by electron transport was the main phenomenon driving the cation flux through the membrane in MEC. The differences between both systems, as observed in an open circuit, could be explained by the difference in the catholytes used in each one.

\subsection{Microbial community assessment}

The microbial community structure of the inoculum and the samples taken from the carbon felt of the MEC and MFC reactors at the end of the assays was characterized by pyrotag $16 \mathrm{~S} r$ RNA gene-based pyrosequencing analysis focused on the total eubacterial and archaeal $165 \mathrm{r} R N A$ gene. 3089, 2115 and 3223 reads and coverage of $0.97,0.96$ and 0.96 were obtained for eubacterial in the inoculum, MFC and MEC anode samples, respectively (Table 4). Regarding archaeal community, 1985, 8469 and 4598 reads were obtained for the inoculum, MFC and MEC anode samples, respectively, and coverage of 0.98 for all three samples. Fig. SI1 


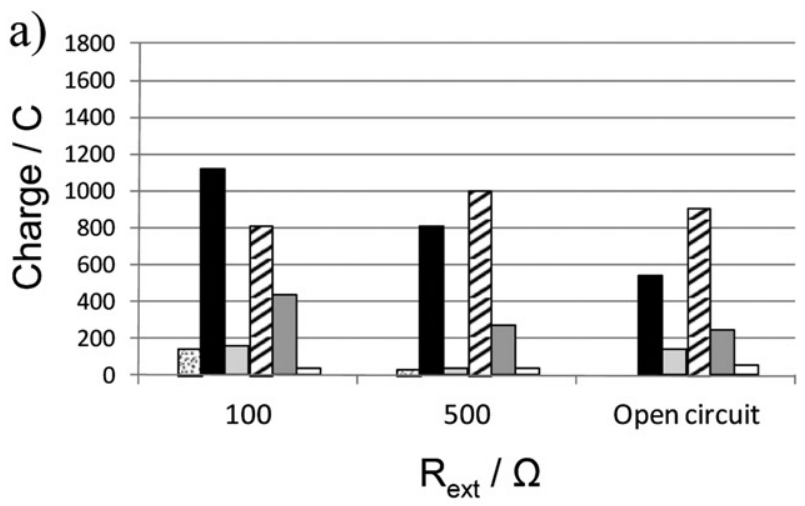

c)

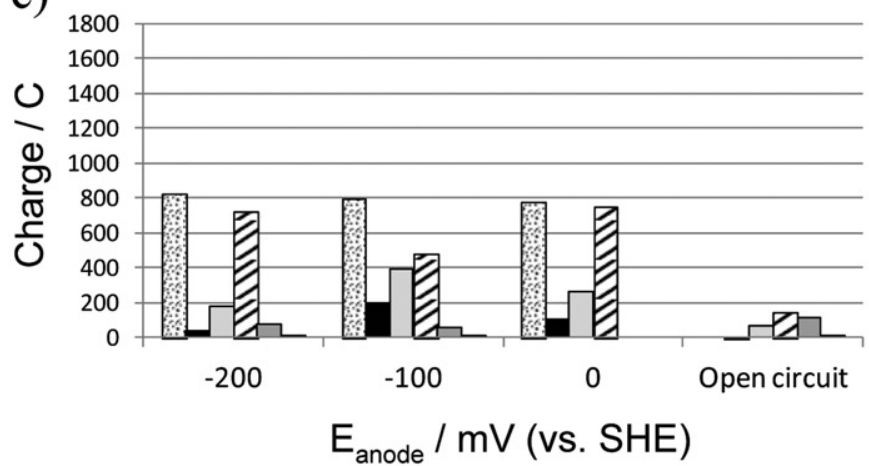

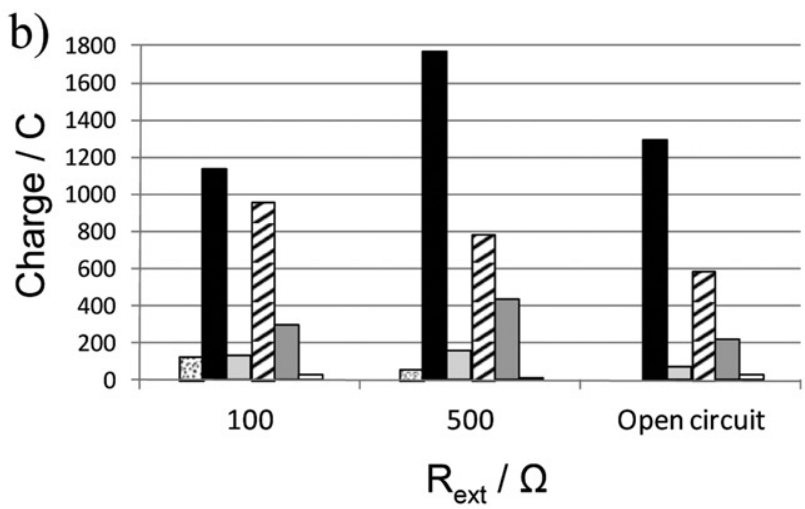

d)

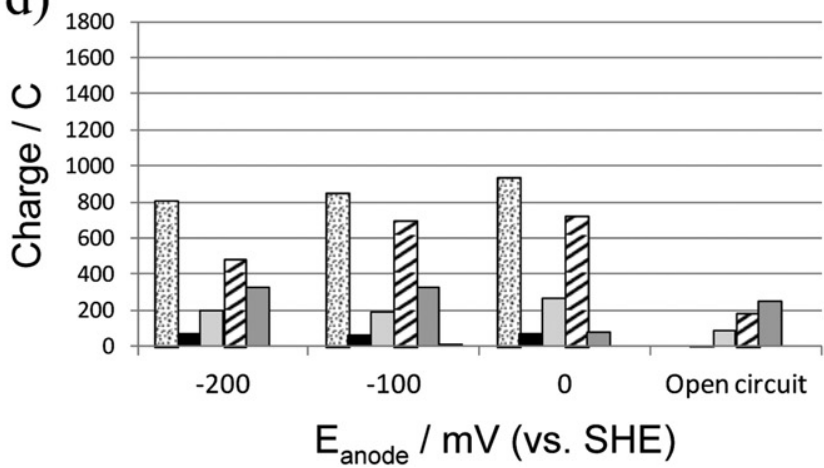

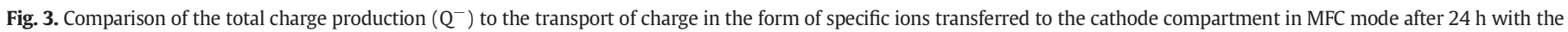

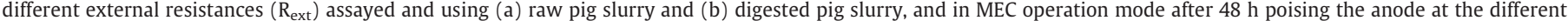

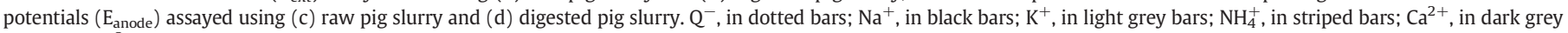
bars; and $\mathrm{Mg}^{2+}$, in white bars.

shows the rarefaction curves, with all samples closer to approaching a plateau when plotting OTUs vs. the number of $16 \mathrm{~S} r R N A$.

Schematic 1a) and Table SI1 show that the three dominant eubacterial phyla identified in the inoculum sample, Proteobacteria, Bacteroidetes and Firmicutes, were also the dominant ones in both the MEC and MFC anodes, although in the MFC mode an enrichment in Bacteroidetes took place. Proteobacteria and Firmicutes are the predominant phyla found on the anode in several MFC systems regardless of MFC configuration, inoculums or substrate $[20,33,36]$. DeltaProteobacteria members were present, although the well-known electrogenic Geobacter sulfurreducens was not detected. A recent study on a MFC working with pig slurry identified $G$. sulfurreducens on the anode by means of fluorescence in situ hybridization (FISH), although it was not detected by polymerase chain reaction-denaturing gradient gel electrophoresis (PCR-DGGE) [37]. When complex organic compounds serve as fuel in BES, it is expected that microorganisms fermenting these substrates into simpler molecules to be also present in the anode microbial community [38]. Although these fermentative microorganisms may have little or no capacity for electron transfer to the anode, their metabolism has a key role to power BES. At the family level, results in Schematic 1b) and Table SI1 revealed the dominance of Desulfuromonadaceae, Clostridiaceae and Porphyromonadaceae in MFC and MEC samples, with a clear enrichment of 2 OTUs belonging to the Desulfuromonadaceae family ( 8 and $18 \%$ of relative predominance, respectively) with respect to the inoculum, where they were not detected.

Table 4

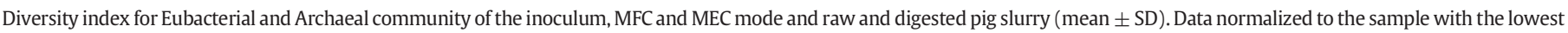

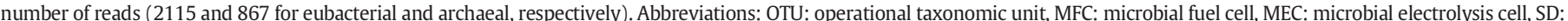
standard deviation.

\begin{tabular}{|c|c|c|c|c|c|c|}
\hline & Reads & Coverage & OTUs & Inverted Simpson & Shannon & Chao \\
\hline \multicolumn{7}{|l|}{ Eubacterial } \\
\hline Inoculum & 3089 & $0.97 \pm 0.00$ & $291.18 \pm 4.03$ & $31.31 \pm 1.12$ & $4.57 \pm 0.02$ & $329.40 \pm 10.90$ \\
\hline MFC & 2115 & $0.96 \pm 0.00$ & $379.00 \pm 0.00$ & $99.96 \pm 0.00$ & $5.31 \pm 0.00$ & $448.05 \pm 0.00$ \\
\hline MEC & 3223 & $0.96 \pm 0.00$ & $371.43 \pm 4.71$ & $43.54 \pm 2.05$ & $5.00 \pm 0.02$ & $421.11 \pm 13.42$ \\
\hline Pig slurry & 3068 & $0.96 \pm 0.00$ & $331.60 \pm 4.42$ & $58.09 \pm 1.73$ & $4.89 \pm 0,02$ & $378.63 \pm 12.31$ \\
\hline Digested pig slurry & 3713 & $0.97 \pm 0.00$ & $232.65 \pm 4.02$ & $28.73 \pm 0.93$ & $4.29 \pm 0.02$ & $263.78 \pm 10.86$ \\
\hline \multicolumn{7}{|l|}{ Archaeal } \\
\hline Inoculum & 1985 & $0.98 \pm 0.00$ & $60.91 \pm 2.84$ & $5.48 \pm 0.22$ & $2.48 \pm 0.04$ & $78.48 \pm 10.74$ \\
\hline MFC & 8469 & $0.98 \pm 0.00$ & $49.62 \pm 3.51$ & $3.67 \pm 0.19$ & $2.10 \pm 0.05$ & $74.57 \pm 16.06$ \\
\hline MEC & 4598 & $0.98 \pm 0.00$ & $52.43 \pm 3.33$ & $3.57 \pm 0.16$ & $2.00 \pm 0.06$ & $73.05 \pm 13.66$ \\
\hline Pig slurry & 867 & $0.99 \pm 0.00$ & $41.00 \pm 0.00$ & $3.65 \pm 0.00$ & $2.07 \pm 0.00$ & $57.50 \pm 0.00$ \\
\hline Digested pig slurry & 7605 & $0.98 \pm 0.00$ & $47.74 \pm 3.84$ & $4.14 \pm 0.18$ & $1.99 \pm 0.05$ & $73.81 \pm 17.37$ \\
\hline
\end{tabular}


a)
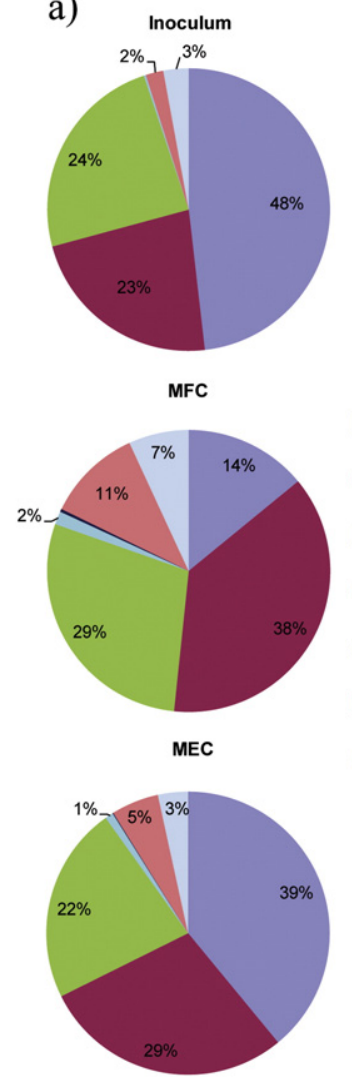

b)

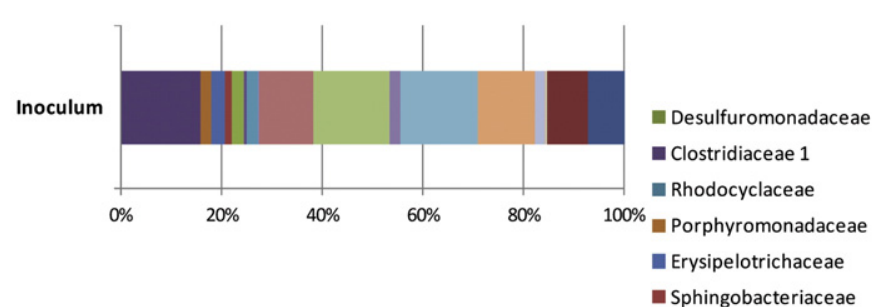

- Proteobacteria

Bacteroidetes

Eirmicutes

- Lentisphaerae

- Synergistetes

- Unclassified

Others

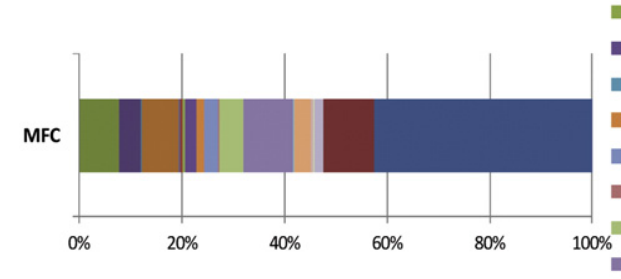

neptostreptococcaceae

- Acholeplasmataceae

Comamonadaceae

- Haloplasmataceae

n Clostridiales_Incertae Sedis XI

Alcaligenaceae

Flavobacteriaceae

Ruminococcaceae

n Chromatiaceae

n Pseudomonadaceae

n Cryomorphaceae

In Synergistaceae

Marinilabiliaceae

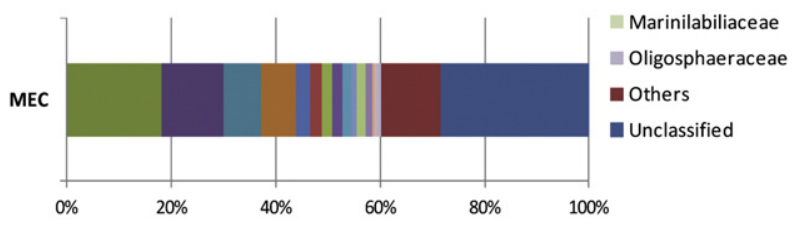

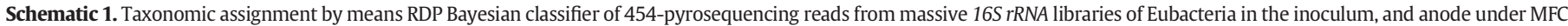

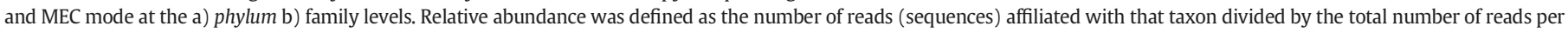
sample. Phylogenetic groups with relative abundance lower that $1 \%$ were categorized as "others".

Regarding microbial diversity, the inverted Simpson, Shannon and Chao1 indexes showed that the sample of the anode in MFC was the most diverse one (99.96, 5.31 and 448.05 respectively), even if the anode potential was lower $(<-300 \mathrm{mV}$ ) than the different potentials assayed in the MEC. A higher diversity is expected with higher anode potentials, as only those microorganisms capable of utilizing minimal energy for growth, respiring at low anode potentials efficiently with minimal energy loss, can live at low potentials [39]. However, the specific conditions applied in our study could have promoted more syntrophic metabolic interactions that could explain a higher diversity at lower potentials. MEC sample indexes were 43.54, 5.00 and 421.11, respectively; while for the inoculum they were $31.31,4.57$ and 329.40 , thus displaying enrichment in diversity during the BES operation (Table 4). In order to know the background populations that could have been provided by the feedings, samples from both the raw and the digested pig slurry were also analysed. The dominant phyla in raw pig slurry were Bacteroidetes (33\%) and Firmicutes (46\%), while in digested pig slurry Proteobacteria represented $44 \%$ of the eubacterial population and Firmicutes did 46\%. At family level, Clostridiaceae accounted for 26 and $15 \%$ for the population of raw and digested pig slurry, respectively, followed by Porphyromonadaceae in raw (7\%) and Pseudomonadaceae in digested pig slurry (39\%) (Fig. SI2). Indeed, a low relative predominance of OTUs belonging to Desulfuromonadaceae (below $0.11 \%$ in digested slurry) was revealed in the feedings.

Correspondence multivariate analysis performed on OTUs' relative distribution among samples indicated that biofilms from the MEC and MFC anodes clustered together, and close to the raw pig slurry sample, while the inoculum and the digested pig slurry samples were clearly separated, indicating that the BES had been enriched in certain groups such as Desulfuromondaceae, with a special relevance of one OTU (13), due to the operation conditions (Fig. SI4(a)).

Regarding archaeal population, Schematic 2 and Table SI2 show an important enrichment in the Thermoplasmatales family on the anode of both BES reactors with respect to the inoculum, representing 83, 61 and $41 \%$, respectively. Thermoplasmata is a novel group of methylotrofic methanogenic archaea that has so far been scarcely described, and which reduces methanol with hydrogen [40] and might also use methylamines as methanogenic substrate [41]. It has been described in anaerobic digesters [42], in pig slurry [43] and in MFC anodes in previous studies $[20,36]$. It has been found that this group was enriched in an UASB with high $\mathrm{NH}_{4}^{+}$concentrations when de OLR was increased [44], which also agrees with the rich ammonia substrates used in this study. The acetotrophic Methanosaetaceae decreased its relative abundance from $41 \%$ in the inoculum down to 11 and $13 \%$ in MFC and MEC anode, respectively, which may reflect the importance of acetate as an anodic substrate, although recently it has been reported that also methanogenic archaea can accept electrons from a solid donor or through direct interspecies electron transfer to reduce carbon dioxide to methane $[45,46]$ though its role in BES processes still needs to be studied in depth. Furthermore, Methanosaetaceae has been described as a more sensible microorganism to high ammonia concentrations [47], and this can explain the shift towards the Thermoplasmatales family, although in a previous study the Methanosaetaceae family has been detected with a relative abundance of over $50 \%$ at the anodes of BES working in MEC and MFC mode with pig slurries with high ammonium concentrations [20]. Regarding archaea composition, raw and digested pig slurries were richer in Methanosaetaceae, representing 56 and 54\%, respectively (Fig. SI3). With respect to microbial diversity, the sample of the 


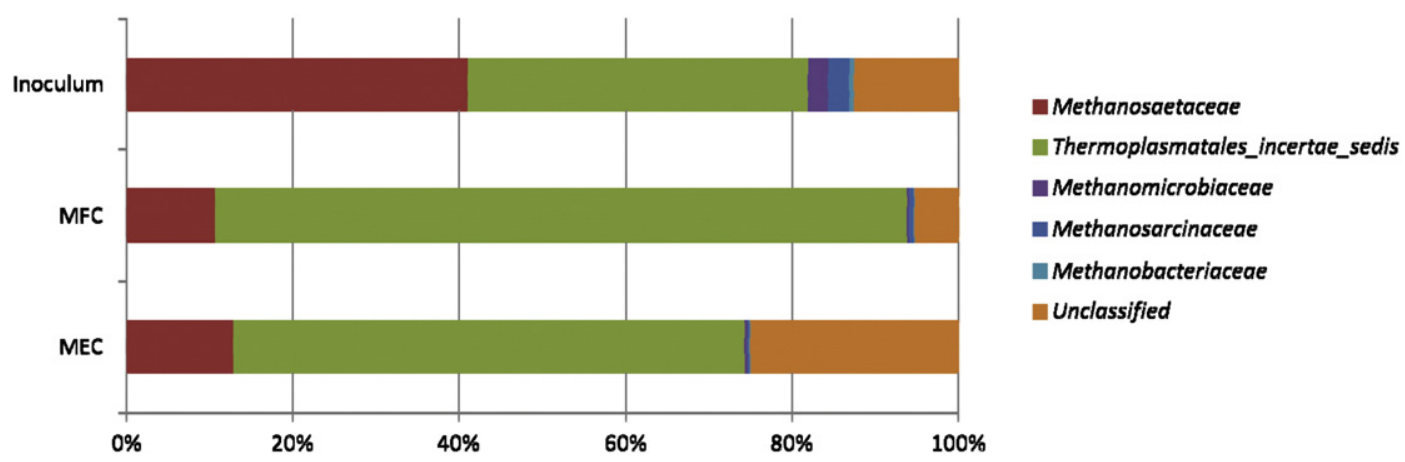

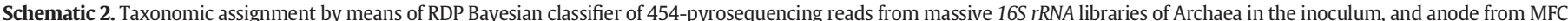

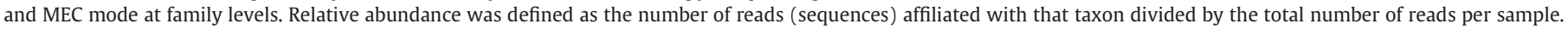
Phylogenetic groups with relative abundance lower that $1 \%$ were categorized as "others".

inoculum was the most diverse one (5.48 (inverted Simpson), 2.48 (Shannon) and 78 (Chao-1)) when compared to the anode biofilm from MFC and MEC mode (Table 4). Correspondence analysis for archaeal population indicated that biofilms from the MEC and MFC anodes clustered together, as in the case of eubacterial population, but in this case they were close to the inoculum sample, while the raw and the digested pig slurry samples were clearly separated (Fig. SI4(b)). OTU 4 , related to Thermoplasmatales, was the predominant one, since it was enriched both in MFC and MEC.

\section{Conclusions}

Batch assays performed with raw and digested pig slurry in MEC and MFC showed that, although COD removals were higher when feeding with raw slurry, $\mathrm{NH}_{4}^{+}$removal efficiencies increased when feeding with digested pig slurry. The AD-MEC integrated system achieved the highest COD removal (60\%) and the maximum $\mathrm{NH}_{4}^{+}$removal efficiency obtained was $40 \%$ (in MFC mode fed with digested pig slurry). The high $\mathrm{pH}$ achieved under MEC mode ( $>10)$, using a $\mathrm{NaCl}$ solution as catholyte, could favour ammonium recovering in a subsequent stripping and absorption process. In the positive charge transport through the cation exchange membrane, ammonia was the main cation involved in maintaining electroneutrality between the two compartments. Finally, the microbial community assessment revealed that Desulfuromonadaceae was highly enriched in MEC mode, and that phylotypes belonging to the potential methylotrofic-hydrogenotrophic methanogen Thermoplasmatales were also favoured against acetotrophic Methanosaetaceae. Consequently, it can be concluded that BES operation in combination with anaerobic digestion is an interesting alternative for the treatment of complex substrates, since a polished effluent can be obtained and ammonium can be recovered for its reuse as fertilizer.

Supplementary data to this article can be found online at http://dx. doi.org/10.1016/j.bioelechem.2016.03.004.

\section{Acknowledgments}

This research was funded by the Spanish Ministry of Economy and Competitiveness (INIA project RTA2012-00096-00-00). The first author was supported by a PhD grant from the Secretariat for Universities and Research of the Ministry of Economy and Knowledge of the Catalan Government (pre-doctoral grant 2013FI_B 00014).

\section{References}

[1] Q. Schiermeier, J. Tollefson, T. Scully, A. Witze, O. Morton, Energy alternatives: electricity without carbon, Nature 454 (2008) 816-823.

[2] R. Kleerebezem, M.C.M. van Loosdrecht, Mixed culture biotechnology for bioenergy production, Curr. Opin. Biotechnol. 18 (2007) 207-212.
[3] A. Bonmatí, X. Flotats, Air stripping of ammonia from pig slurry: characterisation and feasibility as a pre- or post-treatment to mesophilic anaerobic digestion, Waste Manag. 23 (2003) 261-272.

[4] M. Laureni, J. Palatsi, M. Llovera, A. Bonmatí, Influence of pig slurry characteristics on ammonia stripping efficiencies and quality of the recovered ammonium-sulfate solution, J. Chem. Technol. Biotechnol. 88 (2013) 1654-1662.

[5] A. Bonmatí, E. Campos, X. Flotats, Concentration of pig slurry by evaporation: anaerobic digestion as the key process, Water Sci. Technol. 48 (2003) 189-194.

[6] A. Bonmatí, X. Flotats, Pig slurry concentration by vacuum evaporation: influence of previous mesophilic anaerobic digestion process, J. Air Waste Manage. Assoc. 53 (2003) 21-31.

[7] M. Cerrillo, J. Palatsi, J. Comas, J. Vicens, A. Bonmatí, Struvite precipitation as a technology to be integrated in a manure anaerobic digestion treatment plant - removal efficiency, crystal characterisation and agricultural assessment, J. Chem. Technol. Biotechnol. 90 (2015) 1135-1143.

[8] H.M. Hamelers, A. Heijne, TJ.A. Sleutels, A. Jeremiasse, D.B.T.B. Strik C.N. Buisman, New applications and performance of bioelectrochemical systems, Appl. Microbiol. Biotechnol. 85 (2010) 1673-1685.

[9] D. Pant, A. Singh, G. Van Bogaert, S. Irving Olsen, P. Singh Nigam, L. Diels, K. Vanbroekhoven, Bioelectrochemical systems (BES) for sustainable energy production and product recovery from organic wastes and industrial wastewaters, RSC Adv. 2 (2012) 1248-1263.

[10] H. Liu, R. Ramnarayanan, B.E. Logan, Production of electricity during wastewater treatment using a single chamber microbial fuel cell, Environ. Sci. Technol. 38 (2004) 2281-2285.

[11] K.P. Katuri, A.-M. Enright, V. O'Flaherty, D. Leech, Microbial analysis of anodic biofilm in a microbial fuel cell using slaughterhouse wastewater, Bioelectrochemistry 87 (2012) 164-171.

[12] B. Min, J. Kim, S. Oh, J.M. Regan, B.E. Logan, Electricity generation from swine wastewater using microbial fuel cells, Water Res. 39 (2005) 4961-4968.

[13] Z. Ge, F. Zhang, J. Grimaud, J. Hurst, Z. He, Long-term investigation of microbial fuel cells treating primary sludge or digested sludge, Bioresour. Technol. 136 (2013) 509-514.

[14] R.A. Rozendal, T.H. Sleutels, H.V. Hamelers, C.J. Buisman, Effect of the type of ion exchange membrane on performance, ion transport, and $\mathrm{pH}$ in biocatalyzed electrolysis of wastewater, Water Sci. Technol. 57 (2008) 1757-1762.

[15] X. Zhang, F. Zhu, L. Chen, Q. Zhao, G. Tao, Removal of ammonia nitrogen from wastewater using an aerobic cathode microbial fuel cell, Bioresour. Technol. 146 (2013) 161-168.

[16] A. Sotres, M. Cerrillo, M. Viñas, A. Bonmatí, Nitrogen removal in a two-chamber MFC: establishment of nitrifying-denitrifying microbial community on intermittent aerated cathode, Chem. Eng. J. 284 (2016) 905-916.

[17] R. Cord-Ruwisch, Y. Law, K.Y. Cheng, Ammonium as a sustainable proton shuttle in bioelectrochemical systems, Bioresour. Technol. 102 (2011) 9691-9696.

[18] J.R. Kim, Y. Zuo, J.M. Regan, B.E. Logan, Analysis of ammonia loss mechanisms in microbial fuel cells treating animal wastewater, Biotechnol. Bioeng. 99 (2008) 1120-1127.

[19] P. Kuntke, K.M. Smiech, H. Bruning, G. Zeeman, M. Saakes, T.H.J.A. Sleutels, H.V.M. Hamelers, C.J.N. Buisman, Ammonium recovery and energy production from urine by a microbial fuel cell, Water Res. 46 (2012) 2627-2636.

[20] A. Sotres, M. Cerrillo, M. Viñas, A. Bonmatí, Nitrogen recovery from pig slurry in a twochambered bioelectrochemical system, Bioresour. Technol. 194 (2015) 373-382.

[21] N. Zhu, X. Chen, T. Zhang, P. Wu, P. Li, J. Wu, Improved performance of membrane free single-chamber air-cathode microbial fuel cells with nitric acid and ethylenediamine surface modified activated carbon fiber felt anodes, Bioresour. Technol. 102 (2011) 422-426.

[22] APHA, Standard Methods for the Examination of Water and Wastewater, American Public Health Association, American Water Works Association, and Water Pollution Control Federation, Washington, D.C., 1999

[23] M.C.R. Alberto, J.R.M. Arah, H.U. Neue, R. Wassmann, R.S. Lantin, J.B. Aduna, K.F. Bronson, A sampling technique for the determination of dissolved methane in soil solution, Chemosphere Global Change Sci. 2 (2000) 57-63.

[24] S. Lladó, S. Covino, A.M. Solanas, M. Petruccioli, A. D'annibale, M. Viñas, Pyrosequencing reveals the effect of mobilizing agents and lignocellulosic substrate 
amendment on microbial community composition in a real industrial PAH-polluted soil, J. Hazard. Mater. 283 (2015) 35-43.

[25] J.G. Caporaso, J. Kuczynski, J. Stombaugh, K. Bittinger, F.D. Bushman, E.K. Costello, N. Fierer, A. Gonzalez Peña, J.K. Goodrich, J.I. Gordon, G.A. Huttley, S.T. Kelley, D. Knights, J.E. Koenig, R.E. Ley, C.A. Lozupone, D. McDonald, B.D. Muegge, M. Pirrung, J. Reeder, J.R. Sevinsky, P.J. Turnbaugh, W.A. Walters, J. Widmann, T. Yatsunenko, J. Zaneveld, R. Knight, QIIME allows analysis of high-throughput community sequencing data, Nat. Methods 7 (2010) 335-336.

[26] Q. Wang, G.M. Garrity, J.M. Tiedje, J.R. Cole, Naïve bayesian classifier for rapid assignment of rRNA sequences into the new bacterial taxonomy, Appl. Environ. Microbiol. 73 (2007) 5261-5267.

[27] P.D. Schloss, S.L. Westcott, T. Ryabin, J.R. Hall, M. Hartmann, E.B. Hollister, R.A. Lesniewski, B.B. Oakley, D.H. Parks, C.J. Robinson, J.W. Sahl, B. Stres, G.G. Thallinger, D.J. Van Horn, C.F. Weber, Introducing mothur: open-source, platformindependent, community-supported software for describing and comparing microbial communities, Appl. Environ. Microbiol. 75 (2009) 7537-7541.

[28] X. Zhang, W. He, L. Ren, J. Stager, P.J. Evans, B.E. Logan, COD removal characteristics in air-cathode microbial fuel cells, Bioresour. Technol. 176 (2015) 23-31.

[29] S. Haddadi, E. Elbeshbishy, H.-S. Lee, Implication of diffusion and significance of anodic $\mathrm{pH}$ in nitrogen-recovering microbial electrochemical cells, Bioresour. Technol. 142 (2013) 562-569.

[30] P. Kuntke, T.H.J.A. Sleutels, M. Saakes, C.J.N. Buisman, Hydrogen production and ammonium recovery from urine by a microbial electrolysis cell, Int. J. Hydrog. Energy 39 (2014) 4771-4778.

[31] T. Catal, D. Cysneiros, V. O'Flaherty, D. Leech, Electricity generation in singlechamber microbial fuel cells using a carbon source sampled from anaerobic reactors utilizing grass silage, Bioresour. Technol. 102 (2011) 404-410.

[32] Y. Gao, H. Ryu, J.W. Santo Domingo, H.-S. Lee, Syntrophic interactions between H2scavenging and anode-respiring bacteria can improve current density in microbial electrochemical cells, Bioresour. Technol. 153 (2014) 245-253.

[33] A. Bonmatí, A. Sotres, Y. Mu, R.A. Rozendal, K. Rabaey, Oxalate degradation in a bioelectrochemical system: reactor performance and microbial community characterization, Bioresour. Technol. 143 (2013) 147-153.

[34] P. Kuntke, M. Geleji, H. Bruning, G. Zeeman, H.V.M. Hamelers, C.J.N. Buisman, Effects of ammonium concentration and charge exchange on ammonium recovery from high strength wastewater using a microbial fuel cell, Bioresour. Technol. 102 (2011) 4376-4382.

[35] P. Atkins, J. de Paula, Elements of Physical Chemistry, Oxford University Press, Oxford, 2013 (592 pp).

[36] A. Sotres, J. Díaz-Marcos, M. Guivernau, J. Illa, A. Magrí, F.X. Prenafeta-Boldú, A. Bonmatí, M. Viñas, Microbial community dynamics in two-chambered microbial fuel cells: effect of different ion exchange membranes, J. Chem. Technol. Biotechnol. 90 (2015) 1497-1506.

[37] A. Vilajeliu-Pons, S. Puig, N. Pous, I. Salcedo-Dávila, L. Bañeras, M.D. Balaguer, J. Colprim, Microbiome characterization of MFCs used for the treatment of swine manure, J. Hazard. Mater. 288 (2015) 60-68.

[38] S. Jung, J. Regan, Comparison of anode bacterial communities and performance in microbial fuel cells with different electron donors, Appl. Microbiol. Biotechnol. 77 (2007) 393-402.

[39] C.I. Torres, R. Krajmalnik-Brown, P. Parameswaran, A.K. Marcus, G. Wanger, Y.A. Gorby, B.E. Rittmann, Selecting anode-respiring bacteria based on anode potential: phylogenetic, electrochemical, and microscopic characterization, Environmental Science \& Technology 43 (2009) 9519-9524.

[40] K. Paul, J.O. Nonoh, L. Mikulski, A. Brune, "Methanoplasmatales," thermoplasmatalesrelated archaea in termite guts and other environments, are the seventh order of methanogens, Appl. Environ. Microbiol. 78 (2012) 8245-8253.

[41] G. Borrel, N. Parisot, H. Harris, E. Peyretaillade, N. Gaci, W. Tottey, O. Bardot, K. Raymann, S. Gribaldo, P. Peyret, P. O'Toole, J.-F. Brugere, Comparative genomics highlights the unique biology of Methanomassiliicoccales, a thermoplasmatales-related seventh order of methanogenic archaea that encodes pyrrolysine, BMC Genomics 15 (2014) 679

[42] M.C. Nelson, M. Morrison, Z. Yu, A meta-analysis of the microbial diversity observed in anaerobic digesters, Bioresour. Technol. 102 (2011) 3730-3739.

[43] S.O. Petersen, O. Højberg, M. Poulsen, C. Schwab, J. Eriksen, Methanogenic community changes, and emissions of methane and other gases, during storage of acidified and untreated pig slurry, J. Appl. Microbiol. 117 (2014) 160-172.

[44] Z. Chen, Y. Wang, K. Li, H. Zhou, Effects of increasing organic loading rate on performance and microbial community shift of an up-flow anaerobic sludge blanket reactor treating diluted pharmaceutical wastewater, J. Biosci. Bioeng. 118 (2014) $284-288$.
[45] S. Cheng, D. Xing, D.F. Call, B.E. Logan, Direct biological conversion of electrical current into methane by electromethanogenesis, Environmental Science \& Technology 43 (2009) 3953-3958.

[46] A.-E. Rotaru, P.M. Shrestha, F. Liu, M. Shrestha, D. Shrestha, M. Embree, K. Zengler, C. Wardman, K.P. Nevin, D.R. Lovley, A new model for electron flow during anaerobic digestion: direct interspecies electron transfer to Methanosaeta for the reduction of carbon dioxide to methane, Energy Environ. Sci. 7 (2014) 408-415.

[47] C. Zhang, O. Yuan, Y. Lu, Inhibitory effects of ammonia on methanogen mcrA transcripts in anaerobic digester sludge, FEMS Microbiol. Ecol. 87 (2014) 368-377.

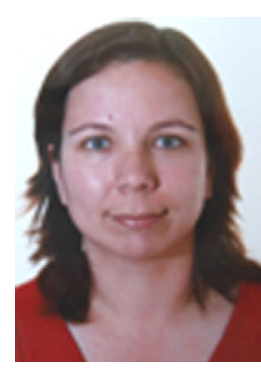

Míriam Cerrillo obtained her BSc degree in Environmental Science in 2002 and MSc degree in Advanced Biotechnology in 2012 at Universitat Autònoma de Barcelona in Spain. She is also a Technical Agricultural Engineer by the University of Vic, Spain, since 2012. She is a PhD student at GIRO Joint Research Unit IRTA-UPC in the Institute of Agrifood Research and Technology (IRTA) in Spain. Her research is focused on the combination of anaerobic digestion and bioelectrochemical systems to improve energy and ammonia recovering.

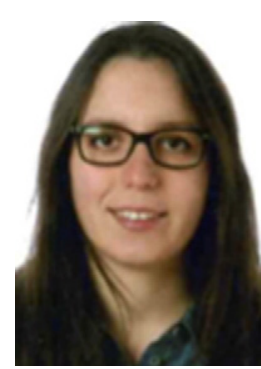

Judit Oliveras earned her degree in Environmental Science at Universitat de Girona and Master's degree in Environmental Engineering at Universitat Politècnica de Catalunya. She developed her master thesis at GIRO Joint Research Unit IRTA-UPC in the Institute of Agrifood Research and Technology (IRTA) in Spain, focused in studying the capability of biolectrochemical systems, operated in MFC and MEC mode, for the treatment of digested pig slurry and ammonia recovering.

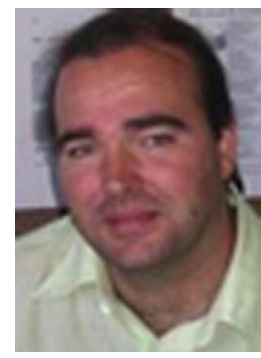

Marc Viñas, PhD in Biology, Environmental Microbiology and Biotechnology, University of Barcelona (UB). He is a researcher at GIRO Joint Research Unit IRTA-UPC in the Institute of Agrifood Research and Technology (IRTA). His research is focused on the microbial ecology linked to the main microbial bioprocesses that occurs in the implementation of different environmental technologies such as bioelectrochemical systems, water treatment, anaerobic digestion and bioremediation of polluted sites.

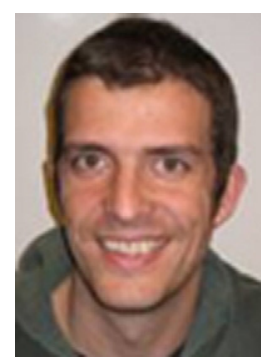

August Bonmatí Blasi, PhD Agricultural Engineer Universidad de Lleida (UdL). He is a researcher at GIRO Join Research Unit IRTA-UPC in the Institute of Agrifood Research and Technology (IRTA). His research is focused on the optimization and development of new treatment technologies for processing wastewater and organic wastes. Energy and products recovery is the main topic of his research. 